\title{
Do IMF Programs Discipline Budget Deficit?: \\ The Effects of IMF Programs on Government Budget Balance, Expenditure, and Revenue*
}

\author{
Hye Jee Cho \\ (The H ong Kong U niversity of Science and Technology)
}

$\langle$ CONTENTS〉

I . Introduction

II. IMF Program Participation and Budget Deficits: Background

1. Previous Studies and Issues

2. The Selection Problem

III. The Effect of IMF Programs on Budget Deficit: Empirical Analysis
1. Dependent Variables

2. Independent Variable

3. Control Variables

4. The Model

5. Results

IV. Conclusion

- Keywords : International Monetary Fund, budget deficit, developing countries, selection bias

\section{【ABSTRACT】}

This article aims to explain the effects of International Monetary Fund (IMF) programs on central government's budget balance, expenditure, and revenue. Previous works in the literature largely ignored the mechanisms by which IMF programs have effects on economic outcomes. Furthermore, earlier studies on the relationship between IMF programs and budget balance suffer from inaccurate measures of budget balance and do not control for the selection bias that is commonly associated with the studies of program participation. This article employs improved measures of budget balance and methods that correct for selection bias in order to analyze the micro-level policy impacts of the IMF through conditionality. Using the data of 93 developing countries from 1951 to 2000, this article finds that IMF programs are effective in reducing government expenditure but fail to increase revenue. Therefore, IMF program participation does not influence overall budget deficits.

* I am very grateful to Kenneth Schultz for his extensive help on this article and James Vreeland for data and comments. I also thank Matthew Baum, Geoffrey Garrett, Ping-Sheng Koh, Barbara Koremenos, Jeffrey Lewis, Barry O’ Neill, Daniel Treisman, and the three anonymous reviewers for their suggestions. All remaining errors are my own. 


\section{I . Introduction}

After a half-century of existence, there are still conflicting views on the importance and effectiveness of the adjustment programs by the International Monetary Fund (IMF). The broad objectives of IMF-supported programs are the attainment of a viable balance of payments, low inflation, and satisfactory long-term growth." Accordingly, studies evaluating IMF programs tend to center on whether the program participation has improved balance of payments and current account balance, lowered inflation, and stimulated growth. ${ }^{2)}$

The literature, however, has largely ignored the mechanisms by which IMF programs achieve their macroeconomic outcomes and has instead attempted to assess whether IMF programs have been "effective" in achieving the broader macroeconomic objectives." Thus, the precise nature of the underlying economic relationships and the specific policies adopted are not made explicit. In other words, it is not clear whether IMF programs have an impact through the policy conditions that are imposed or through other ways; for example, it is difficult to distinguish between the effects of the policies in IMF programs and the effects of IMF finance that accompany the programs. ${ }^{4}$ It is possible that IMF loans have no effect on policy and simply subsidize policy that undermines stabilization, due to government's noncompliance.

The literature is now beginning to look at the question of compliance with policy conditions to understand the effects of IMF programs on macroeconomic outcomes. ${ }^{5}$

1) Moshin Khan, "The Macroeconomic Effects of Fund-Supported Adjustment Programs," IMF Staff Papers 37-2 (1990).

2) For a comprehensive review of earlier studies, refer to Randall Stone, Lending Credibility (Princeton: Princeton University Press, 2002). More recent studies include Axel Dreher, "IMF and Economic Growth: The Effects of Programs, Loans, and Compliance with Conditionality," World Development 34-5 (2006); James Butkiewicz and Halit Yanikkaya, "The Effects of IMF and World Bank Lending on Long-run Economic Growth: An Empirical Analysis," World Development 33-3 (2005); Ruben Atoyan and Patrick Conway, "Evaluating the Impact of IMF Programs: A Comparison of Matching and Instrumental-Variable Estimators," Review of International Organizations 1-2 (2005); Robert Barro and Jong Wha Lee, "IMF-Programs: Who Is Chosen and What Are the Effects?” Journal of Monetary Economics 52 (2005).

3) Khan (1990).

4) Tony Killick, Moazzam Malik, and Marcus Manuel, "What Can We Know about the Effects of IMF Programs?" The World Economy 15-5 (1992), p. 576.

5) Valerie Mercer-Blackman and Anna Unigovskaya, "Compliance with IMF Program Indicators and Growth in Transition Economies," Emerging Markets Finance and Trade 40-3 (2004); Anna Ivanova, Wolfgang Mayer, Alex Mourmouras, and George Anayiotos, "What Determines the Implementation of IMF-supported Programs?" IMF Working Paper 03/8 (2003); Ashoka Mody and Alessandro Rebucci, eds., IMF-Supported Programs: Assessing Program Design, Implementation, and Effectiveness (Washington, D.C.: International Monetary Fund, 2005). 
When a country experiencing a balance of payments problem borrows from the IMF, its government must follow economic and financial policies prescribed by the IMF, a requirement known as conditionality. ${ }^{6}$ ) The conditionality by the IMF includes complex packages of policy measures that have multiple targets and that typically call for fiscal austerity on the part of government, an increase in domestic interest rates, greater investment, trade liberalization, and so on. ${ }^{7)}$ The IMF aims to lay a basis for economic stability and growth by influencing government policy. Therefore, understanding the micro-level policy impacts of the IMF through conditionality enables a better understanding of the effectiveness of IMF programs on macroeconomic outcomes.

This article aims to fill the gap in the literature by focusing on whether IMF programs effectively reduce the budget deficit of a participating country. This issue is important because fiscal austerity is at the heart of IMF-supported programs. The fiscal dimension of macroeconomic management includes policy measures that seek to curtail government expenditures and increase revenues to restore viability to the public sector finance. ${ }^{8)}$ The fiscal adjustment strategies may be tailored to the specific nature of the member country, but on average are intended to increase revenue through tax policy and administrative reforms designed to broaden the revenue base and restrain expenditure. ${ }^{9}$

Despite the ubiquity of the fiscal austerity requirement in IMF conditions, so far only a few studies have addressed the question of IMF programs' effect on budget balance. ${ }^{10)}$

6) Each country that is a member of the Fund (currently 186) contributes a deposit held by the IMF. The IMF then allows its members in distress to borrow foreign exchange from the IMF. By providing countries with loans during financial crises, the IMF plays the role of an international lender of last resort. The conditionality programs require the member country to fulfill agreement obligations and carry out policy reforms accordingly in exchange for financial support from the fund.

7) Khan (1990).

8) Manuel Guitian, “Conditionality: Past, Present, Future," IMF Staff Papers 42-4 (1995), p. 800; Przeworski and Vreeland (2000), p. 388. Such fiscal adjustment strategies underlie the three different types of credit arrangements: stand-by arrangements, extended Fund facility, and the structural adjustment facility. While there are differences among the arrangements, these arrangements share the same fundamental objectives. Przeworski and Vreeland (2000); Quan Li, "IMF Programs and Financial Liberalization in the Developing World," paper presented at the annual meeting of the Midwest Political Science Association, Chicago, Illinois, 2003.

9) James John et al., "IMF Conditionality: Experience under Stand-by and Extended Arrangements," IMF Occasional Papers No. 128 (1995).

10) Patrick Conway, "IMF Lending Programs: Participation and Impact," Journal of Development Economics 45-2 (1994); Killick et al. (1992); Susan Schadler, Franek Rozwadowski, Siddharth Tiwari, and David Robinson, "Economic Adjustment in Low-Income Countries: Experience under the Enhanced Structural Adjustment Facility," International Monetary Fund Occasional Paper No. 106 (1993). 
Those earlier studies lack methods to correct for selection bias that is commonly associated with the studies of program participation. Since countries enter IMF programs when they have economic problems, one needs to control for the selectivity in their participation when estimating the effects of IMF programs. Moreover, earlier studies rely on the measure of budget balance as a proportion of GDP, which could be problematic given some of the earlier studies' findings that IMF programs undermine economic growth. This article addresses the problems of earlier studies by employing a selection model to correct for selection bias and using variables measuring the change in budget balance as well as expenditure and revenue in local currency.

Using the data of 93 developing countries from 1951 to 2000, this article finds that IMF programs are effective in reducing government expenditures but fail to increase revenue. Therefore, IMF program participation does not influence overall budget deficits. The findings suggest that IMF conditionality effectively reduces expenditures while countries are participating in the programs. However, it is difficult to predict the longterm effects of conditionality from the findings. If IMF programs fail to increase revenue even in the long run and simply cut the expenditures, this will create problems in the economy.

This article is organized as follows. First, it briefly reviews previous studies and their shortcomings, namely nonrandom selection and their inaccurate measure of budget deficits. Next, it explains the selection problem and determinants of participation in IMF programs. Lastly, it analyzes the effects of IMF programs on budget deficit, expenditure, and revenue, and suggests the implications of the findings.

\section{II . IMF Program Participation and Budget Deficits: Background}

\section{Previous Studies and Issues}

In the literature on the effectiveness of IMF programs in economic adjustment, only a few studies have tested the effects IMF programs on budget balances. Killick et al. and Schadler et al. evaluate the effects of IMF programs by looking at the performance of countries before entering the program and after the program ends. ${ }^{11}$ They test the effects of IMF programs on balance of payments, inflation and growth, and various policy variables such as exchange rates and debt service in addition to central

11) Killick et al. (1992); Schadler et al. (1993). 
government budget deficits and government expenditures as a proportion of GDP. They find that IMF programs improve governments' budget balances and reduce government consumption. Schadler et al. conclude that IMF programs improve the budget balance as a proportion of GDP in participating countries. Conway uses the generalized evaluation estimator to compare performance in program and non-program countries adjusting for differences in initial conditions among the countries and controlling for exogenous observable influences. ${ }^{12)}$ He finds that IMF programs improve the budget balance as a proportion of GDP and reduces government expenditure over GDP.

One problem with such studies is that they use the measure of budget balance and expenditure as a proportion of GDP. Normalizing some economic variables using GDP is desirable in most cases because it controls for the size of economy among countries. However, it becomes problematic when GDP decreases but the economic variable in question remains the same. Many studies have found that IMF programs are negatively associated with economic growth, implying that IMF programs may reduce GDP in participating countries. ${ }^{13)}$ For example, even when a country's deficit remains the same, it may still appear to be large because GDP, the denominator, is now reduced. Therefore, it would be useful to have a measure of budget balance not as a proportion of GDP in order to correctly assess the impact of IMF programs. ${ }^{14)}$

Another problem with earlier studies concerns the fact that selection into IMF programs is nonrandom. Countries enter the programs when they are experiencing economic difficulties. Most of the previous studies on the effects of IMF programs do not control for selection bias and instead rely on three basic approaches, all of which have difficulties of their own. The first one is the before-after approach, which evaluates the effects of IMF programs by comparing the performance of countries before entering the program and after the program ends. ${ }^{15)}$ The problem with this approach is that it implicitly attributes the impact of extraneous factors to the programs in place. ${ }^{16)}$ Another approach commonly employed in the literature compares the program participant

12) Conway (1994).

13) Morris Goldstein and Peter Montiel, "Evaluating Fund Stabilization Programs with Multicountry Data: Some Methodological Pitfalls," IMF Staff Paper 33 (1986); Khan (1990); Conway (1994); Michael Bordo and Anna Schwartz, "Measuring Real Economic Effects of Bailouts: Historical Perspectives on How Countries in Financial Distress Have Fared with and without Bailouts," NBER Working Paper No. 7701 (2000); Przeworski and Vreeland (2000); James Vreeland, The IMF and Economic Development (Cambridge, UK: Cambridge Universty Press, 2003).

14) For comparison, however, I report the regression results using budget balance/GDP in Appendix 4.

15) Killick et al. (1992); Schadler et al. (1993).

16) Mercer-Blackman and Unigovskaya (2000), p. 5; Vreeland (2003), p. 108. 
countries with similar non-participating countries. The difference in performance is attributed to program participation. ${ }^{17)}$ The problem with this approach is that the observed difference may reflect the conditions which led governments to sign IMF agreements in the first place. ${ }^{18)}$ Third, the generalized evaluation estimator approach corrects for observable determinants of nonrandom selection of program countries by controlling for those observable determinants. This method, however, does not account for the possibility that unobserved factors may also play a role in selection and performance. ${ }^{19)}$ In the next section, I discuss the selection problem in more detail and the methods that I use to correct for it.

\section{The Selection Problem}

To estimate the effects of IMF programs, one must draw inferences about an unobserved counterfactual: in other words, the task is to compare outcomes if countries had participated and not participated in the programs under the same conditions. What one observes in the real world are not experiments, which would match "treatment" and "control" groups, thus permitting direct inferences about the effects of IMF programs. Since the situation of countries that participate in IMF programs differ from those that do not, observed differences in budget deficits may depend on these differing situations as well as the inherent effects of IMF programs. Because selection is not random, one may not always be able to match the observed cases for these conditions. Furthermore, not all of these conditions are observable (e.g., political will and trust that contribute to governments' decision to enter the programs). ${ }^{20}$ A methodology that fails to account for such unobservable variables may result in biased estimates of the effects of IMF programs.

To capture the effects of the relevant unobserved variables, it is necessary to look at the error terms in statistical models. The error term represents unobserved explanatory variables, which are usually assumed to be random disturbances. If the error terms from the estimation of selection into IMF programs are correlated with the errors from the estimation of budget deficits, then the effects of unobserved variables are not random. The correlation indicates that unobserved variables that drive participation also determine performance. The method that corrects for selection effects caused by unobserved variables involves measuring the correlation between the errors from

17) Manuel Pastor, Jr., "The Effects of IMF Programs in the Third World: Debate and Evidence from Latin America," World Development 15-2 (1987); Goldstein and Montiel (1986).

18) Mercer-Blackman and Unigovskaya (2000), p. 5; Vreeland (2003), p. 110.

19) Vreeland (2003), pp. 4-5.

20) Przeworski and Vreeland (2000); Vreeland (2003). 
selection and the errors from performance. This correlation serves as an approximation of the effects of the relevant unobserved variables. These effects can then be removed, leaving the unbiased effects of the IMF treatment.

In this article, I apply the treatment effects model of selectivity to correct for any selection bias using the standard Heckman two-stage procedures. This involves first estimating a program participation equation and then estimating the performance of IMF programs on budget deficits. This method corrects for selection effects caused by unobserved variables by measuring the correlation between the errors from selection and the errors from performance.

Therefore, to evaluate IMF program effects, it is necessary to first understand the criteria for selection into IMF programs. The growing literature on the determinants of selection into IMF programs has identified some important determinants of IMF program participation such as the level of economic development, balance of payments and international reserve needs, lagged elections, debt service and investment. ${ }^{21}$

The level of economic development. The level of economic development is measured by per capita income. Low-income countries are more likely to seek the Fund assistance because they generally have only limited access to private international capital markets. Also, low-income countries may need technical assistance to develop well-functioning institutions. ${ }^{22)}$

Balance of payments and international reserve needs. A country that has a balance of payments and international reserve needs for financial resources is more likely to seek IMF assistance.

Elections in the previous year. Governments are more likely to enter IMF agreements early in their election terms or after elections, hoping that the blame for signing an agreement will be forgotten before the next elections. ${ }^{23)}$

Debt service and investment. When debt service is high, a government is likely to enter IMF programs for financial assistance. Governments are also likely to turn to the IMF when investment is low because a decrease in domestic investment results in decreased revenue for government.

Length of current participation and number of other countries under the program. Countries are more likely to remain in the program in the year right after their first participation year, and the probability to leave the program increases as time goes on.

21) Graham Bird, IMF Lending to Developing Countries: Issues and Evidence (London: Routledge, 1995); Malcolm Knight and Julio Santaella, "Economic Determinants of Fund Financial Arrangements," Journal of Development Economics 54 (1997).

22) Knight and Santaella (1997), p. 419.

23) Przeworski and Vreeland (2000). 
The variable measuring the length of current participation, when included in the model, can control for the temporal dependence of observations. At the same time, the more countries currently participating in an IMF program, the more likely a particular country is to continue participating. Signing an IMF agreement can be costly for the governments that do so because they have to follow IMF conditions and thus sacrifice some sovereignty in return for a loan. Therefore, the sovereignty costs are reduced when many other countries are under IMF programs. ${ }^{24)}$

Budget deficit. A government facing a large budget deficit may turn to the IMF to finance its deficit. In the preliminary regression in Table 1 , I include budget deficit to test whether budget deficit is significantly associated with IMF participation. If so, there would be a simultaneity problem. As it turns out in Table 1, however, budget deficit is not a significant determinant of participation. Therefore, I do not include budget deficit in the models later.

Table 1 shows the result of the probit model on the determinants of the selection into IMF programs. Countries with higher levels of international reserves and investment are less likely to enter the programs. On the other hand, governments with higher levels of debt service are likely to join the programs. As the length of current program participation increases, governments are more likely to exit the program. A country is more likely to be in the program when there are more countries already in the program. Balance of payments and budget deficits are not significantly associated with IMF program participation.

The statistical evidence shows that the selection into IMF programs is not random. However, while this result presents the observed determinants of selection, one still needs to understand that unobserved factors may matter in determining selection into programs. With this preliminary understanding on the selection into IMF programs, I now turn to evaluating the effects of IMF programs on budget deficits.

24) Vreeland (2003), pp. 11, 87. 
Table 1. Determinants of Participation in IMF Programs

\begin{tabular}{ll}
\hline $\begin{array}{c}\text { Dependent Variable: } \\
\text { Participation in IMF programs }\end{array}$ & \multicolumn{1}{c}{$\begin{array}{c}\text { Coefficient } \\
\text { (Standard Error) }\end{array}$} \\
\hline Income & -.05 \\
& $(.06)$ \\
\hline \multirow{2}{*}{ Balance of Payment } & .02 \\
Reserves & $(.02)$ \\
\hline \multirow{2}{*}{ Debt Service } & $-.07^{* * *}$ \\
& $(.02)$ \\
\hline \multirow{2}{*}{ Investment } & $.14^{* *}$ \\
\multirow{2}{*}{ Election } & $(.06)$ \\
\hline \multirow{2}{*}{ Years } & $-.19^{* *}$ \\
& $(.09)$ \\
\hline \multirow{2}{*}{ Number } & -.01 \\
& $(.12)$ \\
\hline \multirow{2}{*}{ Budget deficits } & $-.10^{* *}$ \\
\multirow{2}{*}{ Constant } & $(.04)$ \\
\hline N=1034 & $.01^{* *}$ \\
\end{tabular}

*Significant at $10 \%$ level; **Significant at $5 \%$ level; ***Significant at $1 \%$ level. Log Likelihood $=-430.46$

$\operatorname{LR} \operatorname{chi}^{2}(9)=562.02$

Prob. $>\mathrm{Chi}^{2}=0.0000$

Pseudo $R^{2}=0.40$

All independent variables are lagged by one year.

\section{The Effect of IMF Programs on Budget Deficit: Empirical Analysis}

In this section, I address the main question of this study: do IMF programs discipline budget deficits? I first explain the variables used in the analysis and then present the statistical model as well as the regression results. It is important to note that budget deficit is itself endogenous, affected by the state of the economy as well as affecting it. ${ }^{25}$ This implies potential simultaneity problems between the dependent variable and the control variables. I lag all control variables by one year to avoid simultaneity problems. ${ }^{26)}$

25) Fischer (1989), p. 3.

26) A description of the variables and sources appear in the appendix. 


\section{Dependent Variables}

The main dependent variables in this study are the changes of budget balance, government expenditure, and revenue. The reason for using the change variables is twofold. First, the main focus is on how IMF programs influence the change of a country's fiscal situation. Second, as discussed earlier, budget balance and government expenditure data as a proportion of GDP could be problematic due to IMF programs' negative association with economic growth and GDP. This means data on budget balance and expenditure 'not' measured in GDP terms are required. To concurrently address the negative impact of IMF programs on GDP and different-sized economies, I measure those data as the rate of changes (that is, [value in year $t$ - value in year $t-$ 1]/value in year $t-1$ ). Since I use the dependent variables as change, all of the relevant control variables are changes as well.

\section{Independent Variable}

Participation in IMF programs. A dummy variable is coded 1 for the country-years when there was a conditioned IMF agreement in force, 0 otherwise. I do not distinguish between the four different types of IMF agreements because they share the same fiscal objectives. $^{27)}$

\section{Control Variables}

\section{1) Economic determinants}

Growth rate. Government's budget often depends on the state of the economy. On one hand, there could be a positive relationship between economic output and the expansion of the government spending based on the assumption that pressure for social progress leads to the growth of the public sector; on the other hand, where economic growth is so modest that the government generates insufficient revenues to meet demands for additional public goods, those demands must be met through an expansion of government spending. ${ }^{28)}$ The growth rate can also proxy for the unemployment rate. ${ }^{29)}$

27) Vreeland (2003); Li (2003).

28) David Cameron, "The Expansion of the Public Economy: A Comparative Analysis," American Political Science Review 72 (December 1978).

29) Ideally, one needs to control for the unemployment rate given its significance on budget deficits. However, including unemployment in the regression drastically reduces the number of observations, and hence test power. 
For example, as the economy expands, unemployment falls and, as a result, government expenditure falls in welfare spending. Governments run deficits in recessions and surpluses during economic booms.

Exchange rate regime. Conventional wisdom holds that fixed exchange rates induce more fiscal discipline because adopting lax fiscal policies must eventually lead to an exhaustion of reserves and the collapse of the fixed rate system. On the other hand, Tornell and Velasco argue that flexible rates promote fiscal discipline as they allow the effects of unsound fiscal policies to manifest themselves immediately through movements in the exchange rate, while fixed rates allow the effects to manifest only when the situation becomes unsustainable. ${ }^{30}$ If inflation is costly for the politicians, flexible rates provide more fiscal discipline than fixed rates do. Coded as 1 if flexible exchange rate and 0 if fixed.

\section{2) Structural determinant}

The efficiency of the tax system. An economy with an inefficient tax system cannot collect as large an amount of tax revenues as an economy with an efficient tax system. Two major factors influencing the level of the efficiency of the tax system in a country are variables that account for the sectoral composition of GDP and urbanization. ${ }^{31}$ The larger the relative size of the agricultural sector in an economy, the higher the costs of administration and enforcement of tax collection. This implies a less efficient tax system, thus leading to a larger budget deficit for a given level of government expenditures.

\section{3) Political and institutional determinants}

Political business cycle. This model assumes that politicians attempt to manipulate the economy for electoral purposes. ${ }^{32)}$ Thus, in election years politicians pursue expansionary policies in order to boost the economy in time to secure electoral support from myopic voters (as evidenced by a sample of OECD countries). ${ }^{33)}$

30) Aaron Tornell and Andres Velasco, "Fixed Versus Flexible Exchange Rates: Which Provides More Fiscal Discipline?” NBER Working Paper No. 5108 (1995).

31) Sebastian Edwards and Guido Tabellini, "Explaining Fiscal Policies and Inflation in Developing Countries,” NBER Working Paper No. 3493 (1990); Alex Cukierman, Sebastian Edwards, and Guido Tabellini, "Seigniorage and Political Instability," American Economic Review 82 (1992).

32) William Nordhaus, "The Political Business Cycle," The Review of Economic Studies 42-2 (1975); Edward Tufte, Political Control of the Economy (Princeton: Princeton University Press, 1978).

33) Alberto Alesina, Gerald Cohen, and Nouriel Roubini, "Macroeconomic Policy and Elections in OECD Democracies," Economics and Politics 4 (1992), pp. 1-3; Alberto Alesina, Gerald Cohen, and Nouriel Roubini, "Electoral Business Cycles in Industrial Democracies," European Journal of Political Economy 23 (1993). 
Partisanship of the governing party. Many political economists have argued that parties of the left and right differ in their fiscal policy priorities. ${ }^{34)}$ Specifically, left governments are more willing to expand social welfare programs along with other mechanisms that redistribute wealth. ${ }^{35)}$ The left's pursuit of expansionary policies and generous welfare provisions is likely to lead to a tendency for deficit spending with public indebtedness increasing over time. ${ }^{36)}$

The type of government. Some analysts claim that the type of government affects the size of budget deficits. ${ }^{37)}$ One-party majority governments maintain tighter fiscal discipline, whereas coalition governments are more undisciplined and weaker. The argument is that while a single-party government can easily shift costs to outside members, governing parties in a coalition government are likely to disagree over any fiscal policy that is against their constituencies' interests. Achieving fiscal discipline is facilitated by a broad and consistent fiscal strategy supported by a more consolidated government. As a result, government debt reflects the inability of the government to reach agreement on fiscal policy.

\section{4) Control variables in the selection model}

As shown earlier, selection into IMF programs is not random. If the variables that mattered for inclusion into IMF programs also influence budget balance and government expenditures, those variables also need to be controlled. ${ }^{38)}$ Moreover, those variables are likely to be the determinants of budget balance, government expenditure, and revenue based on the following rationale:

34) Douglas Hibbs, "Political Parties and Macroeconomic Policy," American Political Science Review 71-4 (1977).

35) Cameron (1978); Andre Blais, Donald Blake, and Stephane Dion, "Do Parties Make a Difference? Parties and the Size of Government in Liberal Democracies," American Journal of Political Science 37-1 (1993); Andre Blais, Donald Blake, and Stephane Dion, "Do Parties Make a Difference? A Reappraisal," American Journal of Political Science 40-2 (1996).

36) William Clarke, Matt Golder and Sona Golder, "Fiscal Policy and the Democratic Process in the European Union," European Union Politics 3-2 (2002), p. 6.

37) Nouriel Roubini and Jeffrey Sachs, "Political and Economic Determinants of Budget Deficits in the Industrial Democracies," European Economic Review 33 (1989); Alberto Alesina and Allan Drazen, "Why Are Stabilization Delayed?"American Economic Review 82-4 (1992); Allan Drazen and Vittorio Grilli, "The Benefit of Crises for Economic Reform," American Economic Review 83-2 (1993).

38) The length of current participation is not included in the model because of potential endogeneity problem: just as participation in the IMF is not random, the length of participation is not as well (i.e., countries with a worse economy stay longer in the programs). There is no good way to deal with the endogeneity of this variable because we do not have a model for length of participation. Therefore, one can avoid the problem by dropping this variable. 
Income. Income is particularly relevant to the revenue side of a government budget. Tax revenue grows with increases in income for two reasons: first, there is simply more income to be taxed when people are earning more. Second, as people earn more income, they move into higher tax brackets and the average tax rate that they pay increases. In this article, income is measured by GDP per capita.

International reserves. One way to finance a government budget deficit is to use foreign exchange reserves. ${ }^{39)}$ While the use of international reserves to finance the deficit has a clear limit in that exhaustion of reserves will be associated with currency devaluation and as a result can provoke capital flight and a balance of payments crisis, the government can hope to mitigate the inflationary effects of a deficit compared to financing a deficit by printing money.

Debt service. One way of financing the public sector deficit is direct foreign borrowing. Most of the countries that developed debt servicing difficulties run excessively large public deficits. ${ }^{40)}$

Investment. An increase in domestic investment results in increased revenue for government because governments collect taxes from firms.

Balance of payments. A credit in balance of payments is likely to improve the budget balance of a country because the country has more foreign exchange. If a country has a balance of payment crisis it is likely to have insufficient foreign reserves, which could be a source for deficit financing. ${ }^{41)}$

\section{The Model}

As mentioned earlier, one of the most important design issues for the analysis is that participation in IMF programs is endogenous. Statistical methods are affected by the modeling of this endogenous variable.

The equation that accounts for the effects of IMF programs on budget deficits is

$$
y_{i}=\beta x_{i}+\delta z_{i}+\varepsilon_{i}
$$

where $y_{i}$ denotes budget deficits, $z_{i}$ is a dummy variable indicating whether or not a country participated in IMF programs, and $x_{i}$ is a vector of control variables.

To correct for self-selectivity, one needs the selection equation in addition to the

39) Stanley Fischer, "The Economics of Government Budget Constraint," The World Bank Working Papers No. 224 (1989).

40) Fischer (1989), p. 12.

41) Fischer (1989), pp. 7-13. 
equation on budget deficits (equation [1]). The binary decision to obtain the treatment $z_{i}$ is modeled as the outcome of an unobserved latent variable, $z_{i}^{*}$. It is assumed that $z_{i}^{*}$ is a linear function of the exogenous covariates $w_{i}$ and a random component $u_{i}$. Specifically,

$$
z_{i}^{*}=\gamma W_{i}+u_{i}
$$

and the observed outcome is

$$
Z_{i}=1 \text { if } z_{i}^{*}>0 \text { and } 0 \text { if } z_{i}^{*}<0
$$

The hazard rate, which is the selectivity correction, measures the correlation between the errors from selection and the errors from performance. The foregoing models (1) and (2) each generate error terms $\varepsilon_{i}$ and $u_{i}$, where $\varepsilon_{i}$ accounting for the unobserved variables determining the rate of change of budget balance, and $u_{i}$ for the unobserved variables determining selection into IMF programs. If the selectivity correction is omitted from the least squares regression, then this difference is what is estimated by the least squares coefficient on the treatment dummy variable. To the extent that the error terms are correlated, the unobserved variables that drive participation also determine the size of budget deficits, which will lead to a biased estimator.

\section{Results}

I present three different models for each dependent variable, according to the slightly different model specifications.

Tables 2 to 4 present selection-corrected regressions results on the change of budget balance, government expenditure, and revenue, respectively. ${ }^{42)}$ The variable Hazard accounts for the presence of selection bias in the estimates of parameters in the models. In Table 2, the coefficients are statistically significant in models 1 and 2, indicating that selection bias is present. The IMF participation does not impact the change in budget balance as indicated by the coefficients for IMF which are statistically insignificant. The coefficients for Reserves are statistically significant in all three models and have a positive relationship with budget balance, while flexible exchange rate system is positively associated with budget balance in models I and II. Lastly, leftist governments are likely to be slower in balancing budget than non-leftist governments.

42) I present the OLS estimation results in Appendix 5 for comparison. 
Table 2. The Effect of IMF Programs on the Budget Balance Change

\begin{tabular}{|c|c|c|c|}
\hline & Model I & Model II & Model III \\
\hline IMF & $\begin{array}{l}-35.33 \\
(33.08) \\
\end{array}$ & $\begin{array}{l}-42.91 \\
(33.39) \\
\end{array}$ & $\begin{array}{l}-19.26 \\
(45.11)\end{array}$ \\
\hline Lag & $\begin{array}{l}.05 \\
(.03) \\
\end{array}$ & $\begin{array}{l}.05 \\
(.03) \\
\end{array}$ & $\begin{array}{l}.13^{* * * *} \\
.04)\end{array}$ \\
\hline Income & $\begin{array}{l}-3.36 \\
(4.82)\end{array}$ & $\begin{array}{l}-4.63 \\
(4.93)\end{array}$ & $\begin{array}{l}3.96 \\
(.54)\end{array}$ \\
\hline Growth & $\begin{array}{l}1.56 \\
(4.51) \\
\end{array}$ & $\begin{array}{l}3.08 \\
(4.65)\end{array}$ & $\begin{array}{l}-7.03 \\
(6.16) \\
\end{array}$ \\
\hline BoP & $\begin{array}{l}.002 \\
(.003)\end{array}$ & $\begin{array}{l}.002 \\
(.004)\end{array}$ & $\begin{array}{l}.01 \\
(.01)\end{array}$ \\
\hline Reserves & $\begin{array}{l}.36^{* * * *} \\
.(11)\end{array}$ & $\begin{array}{l}.38^{* * * *} \\
(.11)\end{array}$ & $\begin{array}{l}.59^{* * * *} \\
(.14)\end{array}$ \\
\hline Debt & $\begin{array}{l}-.05 \\
(.04) \\
\end{array}$ & $\begin{array}{l}-.06 \\
(.04) \\
\end{array}$ & $\begin{array}{l}-.12 \\
(.09) \\
\end{array}$ \\
\hline Invest & $\begin{array}{l}.04 \\
(.31) \\
\end{array}$ & $\begin{array}{l}.07 \\
(.31) \\
\end{array}$ & $\begin{array}{l}.06 \\
(.47) \\
\end{array}$ \\
\hline Election & $\begin{array}{l}-13.97 \\
(19.27) \\
\end{array}$ & $\begin{array}{l}-12.75 \\
(19.61) \\
\end{array}$ & $\begin{array}{l}-14.65 \\
(24.76) \\
\end{array}$ \\
\hline Exchange & $\begin{array}{l}40.46^{* *} \\
(16.09) \\
\end{array}$ & $\begin{array}{l}40.87^{* *} \\
(16.67) \\
\end{array}$ & $\begin{array}{l}30.57 \\
(21.32) \\
\end{array}$ \\
\hline Urban & & $\begin{array}{l}-5.11 \\
(5.16) \\
\end{array}$ & \\
\hline Agriculture & & $\begin{array}{l}.59 \\
(.82) \\
\end{array}$ & \\
\hline Left & & & $\begin{array}{l}-43.80 * * \\
(20.75) \\
\end{array}$ \\
\hline Cohesion & & & $\begin{array}{l}-12.46 \\
(12.57) \\
\end{array}$ \\
\hline Constant & $\begin{array}{l}23.16 \\
(22.62) \\
\end{array}$ & $\begin{array}{l}30.90 \\
(24.32) \\
\end{array}$ & $\begin{array}{l}56.12 \\
(31.46) \\
\end{array}$ \\
\hline Hazard & $\begin{array}{l}45.47^{* *} \\
(22.05) \\
\end{array}$ & $\begin{array}{l}52.75^{* *} \\
(22.28) \\
\end{array}$ & $\begin{array}{l}22.65 \\
(29.87) \\
\end{array}$ \\
\hline $\mathrm{N}$ & 1014 & 989 & 557 \\
\hline
\end{tabular}

*Significant at $10 \%$ level; **Significant at $5 \%$ level; ***Significant at $1 \%$ level. Standard errors in parenthesis.

IMF: IMF participation, Lag: lagged dependent variable, Income: GDP per capita, Growth: GDP growth, BoP: balance of payment, Reserves: international reserves, Debt: debt service, Invest: investment, Election: election=1, otherwise 0, Exchange: flexible rate $=1$ fixed=0, Urban: \% of urban population, Agriculture: \% of agriculture sector in the economy, Left: left party in the government=1, otherwise=0, Cohesion: government cohesiveness, Hazard: hazard rate 
Table 3. The Effect of IMF Programs on the Expenditure Change

\begin{tabular}{|c|c|c|c|}
\hline & Model I & Model II & Model III \\
\hline IMF & $\begin{array}{l}-9.30 * * \\
(3.65)\end{array}$ & $\begin{array}{l}-8.62^{* *} \\
(3.68)\end{array}$ & $\begin{array}{l}-10.29 * * \\
(5.20)\end{array}$ \\
\hline Lag & $\begin{array}{l}.49 \\
(.03)\end{array}$ & $\begin{array}{l}.51 \\
(.03)\end{array}$ & $\begin{array}{l}.55^{* * * *} \\
(.04)\end{array}$ \\
\hline Income & $\begin{array}{l}.07^{* * * *} \\
(.02)\end{array}$ & $\begin{array}{l}.07^{* * * *} \\
(.02)\end{array}$ & $\begin{array}{l}.06^{* *} \\
(.03)\end{array}$ \\
\hline Growth & $\begin{array}{l}-1.60 * * * \\
(.25)\end{array}$ & $\begin{array}{l}-1.59 * * * \\
(.25)\end{array}$ & $\begin{array}{l}-1.20 * * * \\
(.37)\end{array}$ \\
\hline $\mathrm{BoP}$ & $\begin{array}{l}.00 \\
(.00)\end{array}$ & $\begin{array}{l}.00 \\
(.00)\end{array}$ & $\begin{array}{l}.00 \\
(.00)\end{array}$ \\
\hline Reserves & $\begin{array}{l}.02 \\
(.01)\end{array}$ & $\begin{array}{l}.02 \\
(.01)\end{array}$ & $\begin{array}{l}.04 * * \\
(.02) \\
\end{array}$ \\
\hline Debt & $\begin{array}{l}-.01 \\
(.004)\end{array}$ & $\begin{array}{l}-.01 \\
(.004)\end{array}$ & $\begin{array}{l}.01 \\
(.01)\end{array}$ \\
\hline Invest & $\begin{array}{l}.05 \\
(.03)\end{array}$ & $\begin{array}{l}.05 \\
(.03)\end{array}$ & $\begin{array}{l}.001 \\
(.05)\end{array}$ \\
\hline Election & $\begin{array}{l}2.95 \\
(2.10)\end{array}$ & $\begin{array}{l}2.71 \\
(2.12)\end{array}$ & $\begin{array}{l}4.14 \\
(2.82)\end{array}$ \\
\hline Exchange & $\begin{array}{l}6.46^{* * *} \\
(1.82) \\
\end{array}$ & $\begin{array}{l}6.31 * * * \\
(1.87) \\
\end{array}$ & $\begin{array}{l}5.01 * * \\
(2.52)\end{array}$ \\
\hline Urban & & $\begin{array}{l}.26 \\
(.54)\end{array}$ & \\
\hline Agriculture & & $\begin{array}{l}.27 * * * \\
(.09)\end{array}$ & \\
\hline Left & & & $\begin{array}{l}-2.58 \\
(2.31)\end{array}$ \\
\hline Cohesion & & & $\begin{array}{l}-.15 \\
(1.37)\end{array}$ \\
\hline Constant & $\begin{array}{l}15.24^{* * * *} \\
(2.59)\end{array}$ & $\begin{array}{l}14.54^{* * * *} \\
(2.80)\end{array}$ & $\begin{array}{l}15.18 * * * \\
(3.80)\end{array}$ \\
\hline Hazard & $\begin{array}{l}6.07^{* *} \\
(2.44)\end{array}$ & $\begin{array}{l}5.85^{* *} \\
(2.46)\end{array}$ & $\begin{array}{l}7.90 * * \\
(3.41)\end{array}$ \\
\hline $\mathrm{N}$ & 1014 & 990 & 546 \\
\hline
\end{tabular}

*Significant at $10 \%$ level; **Significant at 5\% level; ***Significant at $1 \%$ level. Standard errors in parenthesis.

Refer to Table 2 for variable descriptions.

Table 3 shows the regression results on government expenditure change. Countries in IMF programs are likely to reduce the change of government spending by roughly 9 to 10 percent compared to non-participating countries. This is a large effect compared to other control variables. What we are more interested in, however, is the expected potential outcome without the program for the participating countries and the difference between the expected outcomes in the program and without the program. In 
the case of Model I, the average of the expected expenditure change for countries in the IMF programs is 21.53 percent. The average of the predicted values of the change in government expenditure conditional on the absence of treatment (that is, the expected outcome had they not been in the programs) is 30.83 percent. ${ }^{43)}$ Therefore, IMF programs are effective in reducing the rate of increase in government expenditure.

Among other control variables, Growth is negatively associated with government expenditures. Since GDP growth proxies for unemployment, it could be that an increase in growth rate implies a decrease in unemployment rate, thus reducing government expenditures. As the economy grows, unemployment falls, and the result is a decrease in unemployment benefits, welfare payments and food stamp allotments. Overall, a 1 percent increase in the growth rate is associated with $1.2-1.6$ percent decrease in the change of government spending. Income is positively associated with expenditure in all three models. Income proxies for the level of the economy. More advanced economies are likely to have bigger government and therefore larger government expenditures. International reserves also have a positive association with expenditure change. Countries with flexible exchange rate regimes are likely to have higher rate of change in government expenditures by $5-6$ percent. This result confirms the claim that a fixed exchange regime is more likely to discipline government budget balance. Countries that have a larger agricultural sector in the economy are likely to have a higher rate of increase in government spending. Lastly, hazard rates are statistically significant in all three models, indicating the presence of selection bias.

43) The value was calculated using STATA. 
Table 4. The Effect of IMF Programs on Revenue Change

\begin{tabular}{|c|c|c|c|}
\hline & Model I & Model II & Model III \\
\hline IMF & $\begin{array}{l}-7.57^{* * *} \\
(3.64)\end{array}$ & $\begin{array}{l}-7.72 * * \\
(3.63)\end{array}$ & $\begin{array}{l}-8.05^{*} \\
(4.97)\end{array}$ \\
\hline Lag & $\begin{array}{l}.56^{* * * *} \\
(.03)\end{array}$ & $\begin{array}{l}.57^{* * * *} \\
(.03)\end{array}$ & $\begin{array}{l}.60 * * * \\
(.04)\end{array}$ \\
\hline Income & $\begin{array}{l}-.004 \\
(.52)\end{array}$ & $\begin{array}{l}-.10 \\
(.52)\end{array}$ & $\begin{array}{l}-.50 \\
(.66)\end{array}$ \\
\hline Growth & $\begin{array}{l}-.68 \\
(.50)\end{array}$ & $\begin{array}{l}-.53 \\
(.50)\end{array}$ & $\begin{array}{l}-.25 \\
(.63)\end{array}$ \\
\hline $\mathrm{BoP}$ & $\begin{array}{l}.00 \\
(.00)\end{array}$ & $\begin{array}{l}.00 \\
(.00)\end{array}$ & $\begin{array}{l}.00 \\
(.00)\end{array}$ \\
\hline Reserves & $\begin{array}{l}.04 * * * \\
(.01)\end{array}$ & $\begin{array}{l}.03 * * * \\
(.01)\end{array}$ & $\begin{array}{l}.04 * * * \\
(.01)\end{array}$ \\
\hline Debt & $\begin{array}{l}.006 \\
(.004)\end{array}$ & $\begin{array}{l}.007 \\
(.004)\end{array}$ & $\begin{array}{l}.003 \\
(.01)\end{array}$ \\
\hline Invest & $\begin{array}{l}-.04 \\
(.03)\end{array}$ & $\begin{array}{l}-.03 \\
(.03)\end{array}$ & $\begin{array}{l}-.05 \\
(.05)\end{array}$ \\
\hline Election & $\begin{array}{l}6.74 * * * \\
(2.07) \\
\end{array}$ & $\begin{array}{l}6.54 * * * \\
(2.08) \\
\end{array}$ & $\begin{array}{l}7.58^{* * * *} \\
(2.61) \\
\end{array}$ \\
\hline Exchange & $\begin{array}{l}3.24 * * \\
(1.78) \\
\end{array}$ & $\begin{array}{l}3.26 * * \\
(1.80)\end{array}$ & $\begin{array}{l}3.38^{* *} \\
(1.81) \\
\end{array}$ \\
\hline Urban & & $\begin{array}{l}-.02 \\
(.54)\end{array}$ & \\
\hline Agriculture & & $\begin{array}{l}.25^{* * * *} \\
(.09)\end{array}$ & \\
\hline Left & & & $\begin{array}{l}-3.99^{*} \\
(2.15)\end{array}$ \\
\hline Cohesion & & & $\begin{array}{l}-.77 \\
(1.23)\end{array}$ \\
\hline Constant & $\begin{array}{l}13.26^{* * * *} \\
(2.57)\end{array}$ & $\begin{array}{l}13.09^{* *} \\
(3.63)\end{array}$ & $\begin{array}{l}14.85^{* * *} \\
(3.53)\end{array}$ \\
\hline Hazard & $\begin{array}{l}6.09 * * \\
(2.42)\end{array}$ & $\begin{array}{l}6.68^{* * * *} \\
(2.41) \\
\end{array}$ & $\begin{array}{l}7.52^{* *} \\
(3.26)\end{array}$ \\
\hline $\mathrm{N}$ & 888 & 867 & 481 \\
\hline
\end{tabular}

*Significant at $10 \%$ level; **Significant at 5\% level; ***Significant at $1 \%$ level. Standard errors in parenthesis.

Refer to Table 2 for variable descriptions.

Table 4 shows the results of IMF programs effects on the revenue change. Countries in the IMF programs are likely to have a reduction in government revenue. Compared to countries that are not in the programs, countries in IMF programs are likely to have a reduction in the change of revenue of approximately 8 percent. In model I, for countries that are in the program, the expected revenue change had they not been in the programs is 23.04 percent. The expected revenue change for the countries given that 
they are in the program is 30.61 percent. Given the findings by previous studies that IMF programs undermine growth, the results in Table 4 that IMF participation reduces the rate of revenue change are plausible. Increasing revenue is not likely to be as easy as cutting expenditure in many cases, particularly when the economy is bad. Developing countries that rely heavily on foreign capital, when their economy is bad enough to ask for help from the IMF, may experience capital flight because they cause foreign investors to lose confidence in their economy. Furthermore, developing countries usually lack efficient institutional framework for collecting tax and increasing tax base. Traditional IMF conditionality has not successfully addressed such institutional aspect of reform. ${ }^{44)}$

Among the control variables, the variables Reserves, Election, and Exchange are statistically significant in all three models. Election in the previous year is associated with a 7 percent change of an increase in revenue. This phenomenon fits the political business cycle theory, since those won the seats in the election are likely to increase revenue early in their term. International reserves also have a positive relationship with revenue. A 1 percent increase in reserves is associated with $0.3-0.4$ percent increase in revenue. Countries with a flexible exchange regime are likely to have an increase in revenue by approximately 3 percent compared to non-participating countries. The findings also suggest that leftist governments are slower in increasing revenue than right-wing governments. Lastly, a larger agricultural sector is associated with a higher rate of increase in revenue. This finding is contradictory to the claim by Edwards and Tabellini, and Cukierman et al. that the agricultural sector might be the hardest sector of the economy to tax. Lastly, hazard rates are statistically significant in all three cases.

\section{Conclusion}

This article began with the question of whether IMF programs effectively discipline budget balance in participating countries. This research contributes to the literature by addressing the problem of nonrandom selection in analyzing the effects of IMF programs on budget balance, government expenditure, and revenue in developing countries. The findings show that IMF programs are effective in reducing government expenditure in the participating countries. However, the results also indicate that IMF

44) Guitian (1995). 
programs do not increase government revenue. The overall effect of IMF programs on budget balance is indeterminate.

From the results of this study, it is difficult to predict the long-term effects of the programs. It could be that IMF programs are not effective at all in increasing government revenue, and countries under IMF agreements that reduce deficits mainly do so through expenditure cuts. Or it could be that the revenue side policies of IMF programs take effects very slowly. What one can learn from the findings is that conditionality does work at least on the expenditure reduction side. At the same time, if IMF programs fail to increase revenue even in the long run and simply continue to cut expenditures, this will create problems in the economy, particularly when governments will not be able to spend on education and human resources development. Therefore, one important question for future research would be whether IMF programs are effective in the long-term, particularly in increasing revenue.

Overall, the findings of this research bring with them broader lessons for the study of international institutions. On the practical side, policy makers at both national and international levels will find this research valuable. For national policy makers, the findings will carry important implications for the politics of selecting and complying with IMF agreements. At the international level, the findings will help the IMF reassess the adjustment programs and ultimately build an improved international financial architecture. 


\section{REFERENCES}

Alesina, Alberto and Allan Drazen. "Why Are Stabilization Delayed? American Economic Review 82-4 (1991).

Alesina, Alberto, Gerald Cohen, and Nouriel Roubini. "Macroeconomic Policy and Elections in OECD Democracies." Economics and Politics 4 (1992).

. "Electoral Business Cycles in Industrial Democracies." European Journal of Political Economy 23 (1993).

Atoyan, Ruben and Patrick Conway. "Evaluating the Impact of IMF Programs: A Comparison of Matching and Instrumental-Variable Estimators." Review of International Organizations 1-2 (2005).

Barro, Robert and Jong Wha Lee. "IMF-Programs: Who Is Chosen and What Are the Effects?” Journal of Monetary Economics 52 (2005).

Bird, Graham. IMF Lending to Developing Countries: Issues and Evidence. London: Routledge, 1995.

Blais, Andre, Donald Blake, and Stephane Dion. "Do Parties Make a Difference? Parties and the Size of Government in Liberal Democracies," American Journal of Political Science 37-1 (1993).

. "Do Parties Make a Difference? A Reappraisal." American Journal of Political Science 40-2 (1996).

Bordo, Michael and Anna Schwartz. "Measuring Real Economic Effects of Bailouts: Historical Perspectives on How Countries in Financial Distress Have Fared with and without Bailouts.” NBER Working Paper No. 7701 (2000).

Butkiewicz, James and Halit Yanikkaya. "The Effects of IMF and World Bank Lending on Long-Run Economic Growth: An Empirical Analysis.” World Development 33-3 (2005).

Cameron, David. "The Expansion of the Public Economy: A Comparative Analysis." American Political Science Review 72 (December 1978).

Clarke, William, Matt Golder, and Sona Golder. "Fiscal Policy and the Democratic Process in the European Union." European Union Politics 3-2 (2002).

Conway, Patrick. "IMF Lending Programs: Participation and Impact." Journal of Development Economics 45-2 (1994).

Cukierman, Alex, Sebastian Edwards, and Guido Tabellini. "Seigniorage and Political Instability." American Economic Review 82 (1992). 
Drazen, Allan and Vittorio Grilli. "The Benefit of Crises for Economic Reform." American Economic Review 83-2 (1993).

Dreher, Axel. "TMF and Economic Growth: The Effects of Programs, Loans, and Compliance with Conditionality." World Development 34-5 (2006).

Edwards, Sebastian and Guido Tabellini. "Explaining Fiscal Policies and Inflation in Developing Countries." NBER Working Paper No. 3493 (1990).

Fischer, Stanley. "The Economics of Government Budget Constraint." The World Bank Working Papers No. 224 (1989).

Goldstein, Morris and Peter Montiel. "Evaluating Fund Stabilization Programs with Multicountry Data: Some Methodological Pitfalls." IMF Staff Paper 33 (1986).

Guitian, Manuel. “Conditionality: Past, Present, Future." IMF Staff Papers 42-4 (1995).

Hibbs, Douglas. "Political Parties and Macroeconomic Policy." American Political Science Review 71-4 (1977).

Ivanova, Anna, Wolfgang Mayer, Alex Mourmouras, and George Anayiotos. "What Determines the Implementation of IMF-supported Programs?" IMF Working Paper 03/8 (2003).

John, James, Adam Bennett, Maria Vicenta Carkovic S., Louis Dicks-Mireaux, Mauro Mecagni, Miguel A. Savastano, and Susan Schadler. "TMF Conditionality: Experience under Stand-by and Extended Arrangements." IMF Occasional Papers No. 128 (1995).

Khan, Moshin. "The Macroeconomic Effects of Fund-Supported Adjustment Programs." IMF Staff Papers 37-2 (1990).

Killick, Tony, Moazzam Malik, and Marcus Manuel. "What Can We Know about the Effects of IMF Programs?" The World Economy 15-5 (1992).

Knight, Malcolm, and Julio Santaella. "Economic Determinants of Fund Financial Arrangements." Journal of Development Economics 54 (1997).

Li, Quan. "IMF Programs and Financial Liberalization in the Developing World." Paper presented at the annual meeting of the Midwest Political Science Association (2003).

Mercer-Blackman, Valerie, and Anna Unigovskaya. "Compliance with IMF Program Indicators and Growth in Transition Economies." Emerging Markets Finance and Trade 40-3 (2004).

Mody, Ashoka and Alessandro Rebucci, eds. IMF-Supported Programs: Assessing Program Design, Implementation, and Effectiveness. Washington, D.C.: International Monetary Fund, 2005. 
Nordhaus, William. "The Political Business Cycle." The Review of Economic Studies 42-2 (1975).

Pastor, Jr., Manuel. "The Effects of IMF Programs in the Third World: Debate and Evidence from Latin America." World Development 15-2 (1987).

Przeworski, Adam, and James Vreeland. "The Effect of IMF Programs on Economic Growth." The Journal of Development Economics 62 (2000).

Roubini, Nouriel and Jeffrey Sachs. "Political and Economic Determinants of Budget Deficits in the Industrial Democracies." European Economic Review 33 (1989).

Schadler, Susan, Franek Rozwadowski, Siddharth Tiwari, and David Robinson. "Economic Adjustment in Low-Income Countries: Experience under the Enhanced Structural Adjustment Facility.” International Monetary Fund Occasional Paper No. 106 (1993).

Stone, Randall. Lending Credibility. Princeton: Princeton University Press, 2002.

Tornell, Aaron and Andres Velasco. "Fixed Versus Flexible Exchange Rates: Which Provides More Fiscal Discipline?" NBER Working Paper No. 5108 (1995).

Tufte, Edward. Political Control of the Economy. Princeton: Princeton University Press, 1978.

Vreeland, James. The IMF and Economic Development. Cambridge, UK: Cambridge University Press, 2003. 


\section{APPENDICES}

\section{Data sources}

Budget deficit/surplus, total government expenditure, revenue in national currency: International Financial Statistics, World Development Indicators.

IMF: The data are from Vreeland, who originally took them from IMF Annual Reports and IMF Survey.

Income: GDP per capita. World Development Indicators.

BoP: Balance of payments/GDP. IMF's International Financial Statistics.

Reserves: International reserves to imports of goods and services. IMF's International Financial Statistics.

Election: Coded 1 if legislative elections were held the previous country-year. Database of Political Institutions.

Debt service: Total debt service as a proportion of GNI. World Development Indicators.

Debt: The annual debt service as a proportion of GDP. World Development Indicators.

Investment: Real gross domestic investment (private and public) as a percentage of GDP. Penn World Table 6.0.

Years: Cumulative number of years since the last participation in IMF agreements.

Number: Total number of other countries in the world currently under IMF agreements (does not include the given country itself). The data from Vreeland.

Growth: Annual growth rate of GDP. World Development Indicators.

Exchange: Exchange rate regime. IMF's Exchange Arrangements and Restrictions.

Urban: Urban population as a proportion of GDP. World Development Indicators.

Agriculture: Agricultural sector as a proportion of GDP. World Development Indicators.

Left: 1 if left party in government, 0 otherwise. Database of Political Institutions.

Cohesion: Ranges from 0 to 1 , where $0=$ one party majority parliamentary government, or presidential government, with the same party in the majority in the executive and legislative branch; $1=$ coalition parliamentary government with 2 coalition partners or presidential government with different parties in control of executive and legislative branch; $2=$ coalition parliamentary government with 3 or more coalition partners; $3=$ minority parliamentary government. Database of Political Institutions. 


\section{Summary Statistics for variables in Tables $2-4$}

\begin{tabular}{lrrrr}
\hline Variable & \multicolumn{1}{c}{ Mean } & Std.Dev. & \multicolumn{1}{c}{ Min. } & \multicolumn{1}{c}{ Max. } \\
\hline Budget deficit/surplus change & -14.14 & 1101.67 & -23500 & 9380 \\
Expenditure change & 45.10 & 206.96 & -59.24 & 2978.11 \\
Revenue change & 52.94 & 288.48 & -76.7 & 5260 \\
Income & 1.32 & 5.15 & -39.73 & 30.83 \\
Growth & -3.63 & 5.35 & -50.2 & 34.4 \\
Investment & 1.42 & 19.26 & -59.41 & 143.72 \\
Balance of payments & -76.90 & 2092.867 & -26783.86 & 37320.23 \\
Reserves & 11.78 & 67.04 & -98.43 & 1133.04 \\
Debt Service & 24.35 & 210.01 & -98.97 & 5273.98 \\
Election (0,1) & 0.21 & 0.40 & 0 & 1 \\
Exchange (0,1) & 0.41 & 0.49 & 0 & 1 \\
Urban Population & 1.69 & 1.59 & -1.31 & 13.37 \\
Agriculture & -1.51 & 9.87 & -38.76 & 64.22 \\
Left Party & 0.44 & 0.49 & 0 & 1 \\
Cohesion & 0.63 & 0.74 & 0 & 3 \\
\hline
\end{tabular}

\section{Countries in the analysis}

\begin{tabular}{lllll}
\hline Albania & Congo & Honduras & Mauritius & Sri Lanka \\
Argentina & Costa Rica & Hungary & Mexico & Swaziland \\
Azerbaijan & Cote d'Ivoire & India & Moldova & Syrian Arab Rep. \\
Bangladesh & Croatia & Indonesia & Morocco & Tanzania \\
Barbados & Dominican Rep. & Iran & Nepal & Thailand \\
Belarus & Ecuador & Jamaica & Nicaragua & Togo \\
Belize & Egypt & Jordan & Niger & Trinidad\&Tobago \\
Benin & Arab Rep. & Kazakhstan & Nigeria & Tunisia \\
Bolivia & El Salvador & Kenya & Pakistan & Turkey \\
Botswana & Estonia & Korea, South & Panama & Uganda \\
Brazil & Ethiopia & Kyrgyzstan & P. N. Guinea & Uruguay \\
Bulgaria & Fiji & Latvia & Philippines & Venezuela \\
Burkina Faso & Gabon & Lebanon & Poland & Vietnam \\
Burundi & Gambia & Lesotho & Romania & Yemen \\
Cameroon & Ghana & Madagascar & Russia & \\
Chad & Grenada & Malawi & Rwanda & \\
Chile & Guatemala & Malaysia & Senegal & \\
China & Guinea-Bissau & Mali & Sierra Leone & \\
Colombia & Guyana & Malta & Slovak Republic & \\
Comoros & Haiti & Mauritania & South Africa & \\
\hline
\end{tabular}




\section{The Effect of IMF Programs on the Level of Budget Balance, Expenditure, and Revenue as a Proportion of GDP}

\begin{tabular}{|c|c|c|c|c|c|c|c|c|c|}
\hline & \multicolumn{3}{|c|}{ Budget Deficit(-)/Surplus, \% GDP } & \multicolumn{3}{|c|}{ Government Expenditure \% GDP } & \multicolumn{3}{|c|}{ Government Revenue \% GDP } \\
\hline & 1 & II & III & I & II & III & 1 & II & III \\
\hline IMF & $\begin{array}{l}.56 \\
(.48)\end{array}$ & $\begin{array}{l}.49 \\
(.48)\end{array}$ & $\begin{array}{l}.58 \\
(.65)\end{array}$ & $\mid$\begin{tabular}{||l}
.003 \\
$(.07)$
\end{tabular} & $\begin{array}{l}.003 \\
(.02)\end{array}$ & $\begin{array}{l}-.04 \\
(.10)\end{array}$ & $-(.01)$ & $\begin{array}{l}-.01 \\
(.02)\end{array}$ & $\begin{array}{l}-.03 \\
(.03)\end{array}$ \\
\hline Lag & $\begin{array}{l}.73^{* * * *} \\
(.02)\end{array}$ & $\begin{array}{l}.71^{* * *} \\
(.02)\end{array}$ & $\begin{array}{l}.79^{* * * *} \\
(.03)\end{array}$ & \begin{tabular}{|l}
$.92^{* * * *}$ \\
$(.01)$
\end{tabular} & $\begin{array}{l}.91^{* * * *} \\
(.01)\end{array}$ & $\begin{array}{l}.92^{* * * *} \\
(.02)\end{array}$ & $\begin{array}{l}.93 * * * \\
(.01)\end{array}$ & $\begin{array}{l}.93 * * * \\
(.01)\end{array}$ & $\begin{array}{l}.93^{* * * *} \\
(.01)\end{array}$ \\
\hline Income & $\begin{array}{l}.23^{* *} \\
(.11)\end{array}$ & $\begin{array}{l}.25 \\
(.19)\end{array}$ & $\begin{array}{l}.22 \\
(.15)\end{array}$ & \begin{tabular}{|l}
-.00 \\
$(.01)$
\end{tabular} & $\begin{array}{l}-.004 \\
(.01)\end{array}$ & $\begin{array}{l}.002 \\
(.01)\end{array}$ & $\begin{array}{l}.002 \\
(.01)\end{array}$ & $\begin{array}{l}-.003 \\
(.008)\end{array}$ & .01 \\
\hline Growth & $\begin{array}{l}.02 \\
(.02)\end{array}$ & $\begin{array}{l}.02 \\
(.02)\end{array}$ & $\begin{array}{l}.04 \\
(.03)\end{array}$ & $\mid$\begin{tabular}{|l}
.001 \\
$(.001)$
\end{tabular} & $\begin{array}{l}.001 \\
(.001)\end{array}$ & $\begin{array}{l}-.001 \\
(.001)\end{array}$ & $\begin{array}{l}.001 \\
(.00)\end{array}$ & $\begin{array}{l}.001 \\
(.001)\end{array}$ & $\begin{array}{l}-.001 \\
(.001)\end{array}$ \\
\hline $\mathrm{BoP}$ & $\begin{array}{l}-.08 * * * \\
(.03)\end{array}$ & $\begin{array}{l}-.08^{* * * *} \\
(.03)\end{array}$ & $\begin{array}{l}-.07^{*} \\
(.04)\end{array}$ & $\mid \begin{array}{l}-.003^{* *} \\
(.001)\end{array}$ & $\begin{array}{l}-.003^{* *} \\
(.001)\end{array}$ & $\begin{array}{l}-.003 \\
(.002)\end{array}$ & $\begin{array}{l}-.01^{* * * *} \\
(.001)\end{array}$ & $\begin{array}{l}0.01^{* * *} \\
(.001)\end{array}$ & $\begin{array}{l}-.004^{* * * *} \\
(.002)\end{array}$ \\
\hline Reserves & $\begin{array}{l}-.06^{*} \\
(.04)\end{array}$ & $\begin{array}{l}-.04 \\
(.04)\end{array}$ & $\begin{array}{l}-.09 * * \\
(.04)\end{array}$ & $\mid \begin{array}{l}.002 \\
(.002)\end{array}$ & $\begin{array}{l}.001 \\
(.002)\end{array}$ & $\begin{array}{l}.001 \\
(.002)\end{array}$ & $\begin{array}{l}-.001 \\
(.002)\end{array}$ & $\begin{array}{l}-.002 \\
(.002)\end{array}$ & $\begin{array}{l}-.002 \\
(.002)\end{array}$ \\
\hline Debt & $\begin{array}{l}-.17 \\
(.13)\end{array}$ & $\begin{array}{l}-.12 \\
(.13)\end{array}$ & $\begin{array}{l}-.24 \\
(.18)\end{array}$ & \begin{tabular}{||l}
$.009 *$ \\
$(.006)$
\end{tabular} & $\begin{array}{l}.009^{*} \\
(.006)\end{array}$ & $\begin{array}{l}.02 \\
(.01)\end{array}$ & \begin{tabular}{|l}
$.02^{* * * *}$ \\
$(.01)$
\end{tabular} & $\begin{array}{l}.01^{* *} \\
(.01)\end{array}$ & $\begin{array}{l}.02^{* *} \\
(.01)\end{array}$ \\
\hline Invest & $\begin{array}{l}-.05 \\
(.20)\end{array}$ & $\begin{array}{l}-.19 \\
(.20)\end{array}$ & $\begin{array}{l}-.07 \\
(.29)\end{array}$ & $\mid \begin{array}{l}.002 \\
(.006)\end{array}$ & $\begin{array}{l}.003 \\
(.01)\end{array}$ & $\begin{array}{l}.01 \\
(.02)\end{array}$ & $(.01)$ & $\begin{array}{l}.01 \\
(.01)\end{array}$ & $\begin{array}{l}.02 \\
(.01)\end{array}$ \\
\hline Election & $\begin{array}{l}.38 \\
(.24)\end{array}$ & $\begin{array}{l}.37 \\
(.23)\end{array}$ & $\begin{array}{l}.40 \\
(.31)\end{array}$ & $\mid \begin{array}{l}-.01 \\
(.01)\end{array}$ & $\begin{array}{l}-.01 \\
. .01)\end{array}$ & $\begin{array}{l}-.01 \\
(.02)\end{array}$ & \begin{tabular}{|l}
$.02 *$ \\
$(.01)$
\end{tabular} & $\begin{array}{l}.01 \\
(.01)\end{array}$ & $\begin{array}{l}.02 \\
(.01)\end{array}$ \\
\hline Exchange & $\begin{array}{l}-.09 \\
(.19)\end{array}$ & $\begin{array}{l}-.12 \\
(.20)\end{array}$ & $\begin{array}{l}.01 \\
(.27)\end{array}$ & \begin{tabular}{|l}
$-.02 * *$ \\
$(.01)$
\end{tabular} & $\begin{array}{l}-.03^{* * *} \\
(.01)\end{array}$ & $\begin{array}{l}-.02^{* *} \\
(.01)\end{array}$ & $\mid \begin{array}{l}-.02 \\
(.01)\end{array}$ & $\begin{array}{l}-.02 \\
(.01)\end{array}$ & $\begin{array}{l}-.01 \\
(.01)\end{array}$ \\
\hline Urban & & $\begin{array}{l}-.01 \\
(.01)\end{array}$ & & & $\begin{array}{l}.00 \\
(.00)\end{array}$ & & & $\begin{array}{l}1.96 e^{-7} \\
(9.00)\end{array}$ & \\
\hline Agriculture & & $\begin{array}{l}-.01 \\
(.01)\end{array}$ & & & $\begin{array}{l}-.00 \\
(.00)\end{array}$ & & & $\begin{array}{l}-.001 \\
(.001)\end{array}$ & \\
\hline Left & & & $\begin{array}{l}-.34 \\
(.27)\end{array}$ & & & $\begin{array}{l}-.001 \\
(.01)\end{array}$ & & & $\begin{array}{l}-.004 \\
(.01)\end{array}$ \\
\hline Cohesion & & & $\begin{array}{l}-.05 \\
(.16)\end{array}$ & & & $\begin{array}{l}.01 \\
(.01)\end{array}$ & & & $\begin{array}{l}.01 \\
(.01)\end{array}$ \\
\hline Constant & $\begin{array}{l}-3.55^{* *} \\
(1.38)\end{array}$ & $\begin{array}{l}-2.59 \\
(1.81)\end{array}$ & $\begin{array}{l}-3.54^{* *} \\
(1.87)\end{array}$ & \begin{tabular}{|l}
$.31 * * *$ \\
$(.07)$
\end{tabular} & $\begin{array}{l}.35^{* * * *} \\
(.09)\end{array}$ & $\begin{array}{l}.37^{* * *} \\
(.10)\end{array}$ & \begin{tabular}{|l}
$.25^{* * * *}$ \\
$(.06)$
\end{tabular} & $\begin{array}{l}.31^{* * * *} \\
(.09)\end{array}$ & $\begin{array}{l}.22^{* * * *} \\
(.08)\end{array}$ \\
\hline Hazard & $\begin{array}{l}-.14 \\
(.31)\end{array}$ & $\begin{array}{l}-.16 \\
(.31)\end{array}$ & $\begin{array}{l}-2.50 \\
(.42) \\
\end{array}$ & \begin{tabular}{|l}
.005 \\
$(.01)$
\end{tabular} & $\begin{array}{l}.005 \\
(.01)\end{array}$ & $\begin{array}{l}.03 \\
(.02) \\
\end{array}$ & $\begin{array}{l}.02 \\
(.01) \\
\end{array}$ & $\begin{array}{l}.02 \\
(.01)\end{array}$ & \begin{tabular}{|l}
.02 \\
$(.02)$ \\
\end{tabular} \\
\hline N & 1198 & 1170 & 660 & 980 & 961 & 558 & 985 & 969 & 569 \\
\hline
\end{tabular}

*Significant at $10 \%$ level; **Significant at $5 \%$ level; ***Significant at $1 \%$ level. Standard errors in parenthesis. 
5. The Effect of IMF Programs on the change of Budget Balance, Expenditure, and Revenue: OLS Estimation (not correcting selection bias)

\begin{tabular}{|c|c|c|c|c|c|c|c|c|c|}
\hline & Budget & ficit(-)/Su & us Change & Governme & nt Expendity & ure Change & Governn & ent Reven & e Change \\
\hline & 1 & II & III & 1 & II & III & 1 & II & III \\
\hline IMF & $\begin{array}{l}25.68 \\
(16.43)\end{array}$ & $\begin{array}{l}25.68 \\
(16.43)\end{array}$ & $\begin{array}{l}10.95 \\
(21.33)\end{array}$ & $\begin{array}{l}-1.36 \\
(1.74)\end{array}$ & $\begin{array}{l}-.98 \\
(1.77)\end{array}$ & $\begin{array}{l}.27 \\
(2.43)\end{array}$ & $\begin{array}{l}\mid .43 \\
(1.74)\end{array}$ & $\begin{array}{l}1.02 \\
(1.75)\end{array}$ & $\begin{array}{l}2.10 \\
(2.26)\end{array}$ \\
\hline Lag & $\begin{array}{l}.05 \\
(.03)\end{array}$ & $\begin{array}{l}.05 \\
(.03)\end{array}$ & $\begin{array}{l}.14^{* * * *} \\
(.04)\end{array}$ & $\begin{array}{l}.50^{* * * *} \\
(.03)\end{array}$ & $\begin{array}{l}.52^{* * *} \\
(.03)\end{array}$ & $\begin{array}{l}.57^{* * * *} \\
(.04)\end{array}$ & $\mid \begin{array}{l}.57 * * * \\
(.03)\end{array}$ & $\begin{array}{l}.58^{* * * *} \\
(.03)\end{array}$ & $\begin{array}{l}.61^{* * * *} \\
(.04)\end{array}$ \\
\hline Income & $\begin{array}{l}-1.77 \\
(4.79)\end{array}$ & $\begin{array}{l}-2.81 \\
(4.92)\end{array}$ & $\begin{array}{l}4.46 \\
(6.52)\end{array}$ & $\begin{array}{l}.08^{* * *} \\
(.02)\end{array}$ & $\begin{array}{l}.08^{* * * *} \\
(.02)\end{array}$ & $\begin{array}{l}.07^{* *} \\
(.03)\end{array}$ & $\mid \begin{array}{l}.20 \\
(.52)\end{array}$ & $\begin{array}{l}.13 \\
(.52)\end{array}$ & $\begin{array}{l}-.41 \\
(.68)\end{array}$ \\
\hline Growth & $\begin{array}{l}.49 \\
(4.52)\end{array}$ & $\begin{array}{l}1.82 \\
(4.67)\end{array}$ & $\begin{array}{l}-7.26 \\
(6.22)\end{array}$ & $\begin{array}{l}-1.64^{* * *} \\
(.25)\end{array}$ & $\begin{array}{l}-1.65^{* * * *} \\
(.25)\end{array}$ & $\begin{array}{l}-1.21^{* * *} \\
(.37)\end{array}$ & $\mid \begin{array}{l}-.82^{*} \\
(.50)\end{array}$ & $\begin{array}{l}-.70 \\
(.51)\end{array}$ & $\begin{array}{l}-.25 \\
(.64)\end{array}$ \\
\hline $\mathrm{BoP}$ & $\begin{array}{l}.003 \\
(.004)\end{array}$ & $\begin{array}{l}.003 \\
(.004)\end{array}$ & $\begin{array}{l}.01 \\
(.01)\end{array}$ & $\begin{array}{l}.00 \\
(.00)\end{array}$ & $\begin{array}{l}.00 \\
(.00)\end{array}$ & .00 & $\mid \begin{array}{l}.00 \\
(.00)\end{array}$ & $\begin{array}{l}.00 \\
(.00)\end{array}$ & $\begin{array}{l}.00 \\
(.00)\end{array}$ \\
\hline Reserves & $\begin{array}{l}.37^{* * * *} \\
(.11)\end{array}$ & $\begin{array}{l}.38^{* * *} \\
(.12)\end{array}$ & $\begin{array}{l}.59^{* * * *} \\
(.14)\end{array}$ & $\begin{array}{l}.02^{* *} \\
(.01)\end{array}$ & $\begin{array}{l}.02^{* *} \\
(.01)\end{array}$ & $\begin{array}{l}.04^{* * *} \\
(.02)\end{array}$ & $\mid \begin{array}{l}.04^{* * *} \\
(.01)\end{array}$ & $\begin{array}{l}.03^{* * * *} \\
(.01)\end{array}$ & $\begin{array}{l}.04^{* * * *} \\
(.01)\end{array}$ \\
\hline Debt & $\begin{array}{l}-.05 \\
(.04)\end{array}$ & $\begin{array}{l}-.05 \\
(.04)\end{array}$ & $\begin{array}{l}-.12 \\
(.10)\end{array}$ & $\begin{array}{l}-.01^{* *} \\
(.004)\end{array}$ & $\begin{array}{l}-.01^{* *} \\
(.004)\end{array}$ & $\begin{array}{l}.01 \\
(.01)\end{array}$ & $\mid .01$ & $\begin{array}{l}.01 \\
(.004)\end{array}$ & $\begin{array}{l}.002 \\
(.01)\end{array}$ \\
\hline Invest & $\begin{array}{l}.01 \\
(.31)\end{array}$ & .03 & $\begin{array}{l}.06 \\
(.48)\end{array}$ & $\begin{array}{l}.05 \\
(.03)\end{array}$ & .05 & .01 & $\mid \begin{array}{l}-.05 \\
(.03)\end{array}$ & $\begin{array}{l}-.04 \\
(.03)\end{array}$ & $\begin{array}{l}-.05 \\
(.05)\end{array}$ \\
\hline Election & $\begin{array}{l}-14.89 \\
(19.24)\end{array}$ & $\begin{array}{l}-13.91 \\
(19.56)\end{array}$ & $\begin{array}{l}-15.83 \\
(24.96)\end{array}$ & $\begin{array}{l}2.79 \\
(2.09)\end{array}$ & $\begin{array}{l}2.53 \\
(2.11)\end{array}$ & $\begin{array}{l}3.60 \\
(2.79)\end{array}$ & \begin{tabular}{||l}
$6.67 * * *$ \\
$(2.06)$
\end{tabular} & $\begin{array}{l}6.45^{* * *} \\
(2.07)\end{array}$ & $\begin{array}{l}7.08^{* * * *} \\
(2.58)\end{array}$ \\
\hline Exchange & $\begin{array}{l}36.66 \\
(16.09)\end{array}$ & $\begin{array}{l}35.82 \\
(16.68)\end{array}$ & $\begin{array}{l}27.56 \\
(21.20)\end{array}$ & $\begin{array}{l}5.97 * * * \\
(1.82)\end{array}$ & $\begin{array}{l}5.77^{* * * *} \\
(1.87)\end{array}$ & $\begin{array}{l}3.81 \\
(2.51)\end{array}$ & $\begin{array}{l}2.37 \\
(1.76)\end{array}$ & $\begin{array}{l}2.24 \\
(1.78)\end{array}$ & $\begin{array}{l}1.34 \\
(2.26)\end{array}$ \\
\hline Urban & & $\begin{array}{l}-4.88 \\
(5.19)\end{array}$ & & & $\begin{array}{l}.28 \\
.54)\end{array}$ & & & $\begin{array}{l}.04 \\
(.55)\end{array}$ & \\
\hline Agriculture & & .45 & & & $\begin{array}{l}.26^{* * *} \\
(.09)\end{array}$ & & & $\begin{array}{l}.24^{* *} \\
(.09)\end{array}$ & \\
\hline Left & & & $\begin{array}{l}-45.51^{* *} \\
(20.87)\end{array}$ & & & $\begin{array}{l}-3.09 \\
(2.34)\end{array}$ & & & $\begin{array}{l}-4.46^{* * *} \\
(2.19)\end{array}$ \\
\hline Cohesion & & & $\begin{array}{l}-12.35 \\
(12.72)\end{array}$ & & & $\begin{array}{l}-.11 \\
(1.39)\end{array}$ & & & $\begin{array}{l}-.76 \\
(1.26)\end{array}$ \\
\hline Constant & $\begin{array}{l}-7.04 \\
(.68)\end{array}$ & $\begin{array}{l}-3.65 \\
(19.46)\end{array}$ & $\begin{array}{l}42.47 \\
(26.09)\end{array}$ & $\begin{array}{l}10.52^{* * *} \\
(1.75)\end{array}$ & $\begin{array}{l}10.06^{* * *} \\
(2.08)\end{array}$ & $\begin{array}{l}9.81^{* * *} \\
(3.03)\end{array}$ & \begin{tabular}{|l}
$9.18^{* * * *}$ \\
$(1.99)$
\end{tabular} & $\begin{array}{l}8.65^{* * *} \\
(2.18)\end{array}$ & $\begin{array}{l}10.08^{* * *} \\
(2.87) \\
\end{array}$ \\
\hline $\mathrm{N}$ & 1014 & 989 & 557 & 1014 & 990 & 546 & 888 & 867 & 481 \\
\hline Adjusted R & .02 & .02 & .06 & .30 & .31 & .33 & .34 & .35 & .43 \\
\hline
\end{tabular}

*Significant at $10 \%$ level; ${ }^{* *}$ Significant at $5 \%$ level; ***Significant at $1 \%$ level. Standard errors in parenthesis. 